\title{
Dermatoglyphics and Its Relation to Intelligence Levels of Young Students
}

\author{
${ }^{1}$ Dr. K. Lakshmi Kumari . ${ }^{2}$ Dr. P. V. S. S.Vijaya Babu. ${ }^{3}$ Dr. S. V. Kumar. \\ ${ }^{I}$.Assistant Professor, Department of Anatomy, Andhra Medical College, Visakhapatnam, INDIA \\ ${ }^{2}$ Assistant Professor, Department of Biochemistry, Andhra Medical College, Visakhapatnam,INDIA \\ ${ }^{3}$ Professor of Surgery, Department of Surgery, Andhra Medical College, Visakhapatnam,INDIA
}

\begin{abstract}
Dermatoglyphics is the study of dermal ridges on palms and soles. Dermatoglyphics starts its development in $3^{\text {rd }}$ month and completes by $5^{\text {th }}$ month. Human beings are possessing their unique blend of intelligence. Human intelligence and dermatoglyphics, both are influenced by genetic factors. The aim of this study is to relate dermatoglyphics and human intelligence in young individuals pursuing medical graduation and medical lab technician courses. Subjects are 94 medical students pursuing first year of medical graduation course in Medical College and 80 students pursuing Medical lab technician course in the same college. Both groups have passed through common secondary education. Finger prints of each subject were collected by ink printing method. The pattern of finger prints were identified and analyzed. Finger prints pattern of most of the subjects are whorls and ulnar loops.Ulnar loops shows slightly increased prevalence in left hand of the medical students. Medical Lab technology students are having more number of whorl patterns in both hands.
\end{abstract}

Key words: Dermatoglyphics, Young individuals, Whorl pattern, Ulnar loops,Study.

\section{Introduction}

Dermatoglyphics is the study of the finger prints and can be traced back to 1892 by Sir Francis Galton, a cousin of Charles Darwin, published his non classical work on finger prints. Dermatoglyphics or epidermal ridge configuration is the study of dermal ridges on palms, finger tips and soles. This epidermal ridge configuration starts appear in the third month of intrauterine life and completes its development by fifth month of intrauterine life $\mathrm{e}^{1,2,3}$ and remain unaltered throughout the life except for an increase in size in parallel with general growth of the individual. ${ }^{4}$ Disturbances can be caused by diseases such as fetal rubella, thalidomide poisoning ${ }^{2}$, chromosomal aberrations ${ }^{5,6}$, maternal stress during prenatal period ${ }^{7,8,9}$.

Different types of finger print patterns were identified by the standard method set by Cummins and Midlo $1943^{10}$.Four main types of finger print patterns sere classified as whorl, ulnar loop, radial loop and arch. Human beings are possessing their unique blend of intelligence ${ }^{11}$. Though Gardeners theory of multiple intelligence has not been readily accepted. The factors affecting human intelligence are biological endowment including genes and brain injuries during development, personal life history and cultural back ground ${ }^{12}$.The finger print pattern is also inherited from many genes ${ }^{13}$ and prenatal environment ${ }^{7,8,9}$.

This study is to associate the intelligence level of young individuals with dermoglyphics. In previous studies ${ }^{14}$ each finger is connected with one brain lobe plus a specific type of intelligence and each type of fingerprint is connected with the following type of learning.

Whorl-Cognitive learning.

Ulnar Loop- Affective Learning.

Radial Loop- Critical Thinking.

Tented Arch- Enthusiastic Learning.

Arch -Reflective Learning.

Since 1823 scientists have discovered that finger prints and innate intelligence are related. Through many medical researches it is found that finger prints are formed during the $13^{\text {th }}$ to $19^{\text {th }}$ prenatal week. The neocortex is developed during the same period. Many studies integrate genetics, embryology, dermatoglyphics and neural sciences with multiple intelligence. In studies finger prints of intellectually disabled people is different from that of normal persons .

\section{Material And Methods}

Subjects:- A total of 94 medical students who are pursuing first M.B.,B.S. in Medical College, Visakhapatnam, Andhra Pradesh, India, a total of 80 students pursuing Medical lab technician course in same college, were participated in the study. Both the groups have completed their common secondary education in biological sciences. One group have selected for medical graduation through common competitive examination .Another group who have not selected in common competitive examination, opted for Medical lab technician course. Since the common competitive examination is a tool for selecting better intelligent students, we thought 
that both group may vary in intelligence levels. For obtain finger print patterns of both groups, ink print method had been adopted. The traditional means of fingerprinting was developed by Dr.Henry Faulds in the late 1800.The ink is applied to the finger and is rolled across a piece of paper. The ink and paper method of finger printing is effective.

Step 1:- Both hands of the student were cleaned with alcohol

Step 2:- 2:1 Mixture of glycerin and ink was applied to the tips of both hands

Step 3:- Excess of ink was removed

Step 4:- The impressions were collected by rolling the fingers in $45^{\circ}$ from one side to other side on writing paper.

Data analysis:- Types of finger print pattern were identified by the standard method set by Cummins and Midlo(1943).Four main types of finger print pattern were classified as whorl, ulnar loop, radial loop and arch.

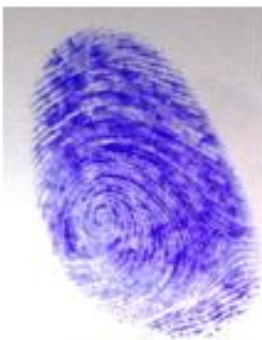

Whorl

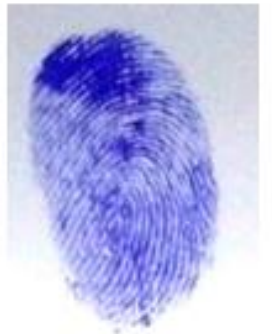

Ulnar loop

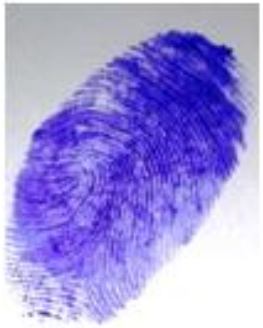

Radial loop

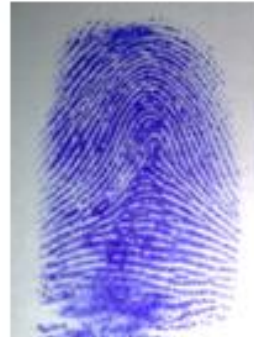

Arch

\section{Results}

In our study most frequent dermatoglyphic patterns seen on all fingers of both groups are ulnar loops and whorls. Despite the fact that the frequencies of digital patterns in the normal populations has established by various studies differ around the world, it has also been reported that ulnar loops and whorls are the most common finger print patterns ${ }^{15}$ (Reed T, Dermatoglyphics 1979).

\begin{tabular}{|c|c|c|c|c|c|c|c|c|c|c|}
\cline { 2 - 11 } & LT & LIF & LMF & LRF & LLF & RT & RIF & RMF & RRF & RLF \\
\hline Pattern & L1 & L2 & L3 & L4 & L5 & R1 & R2 & R3 & R4 & R5 \\
\hline Whorls & $\mathbf{5 7 . 5}$ & $\mathbf{5 7 . 1}$ & 31.6 & 61.1 & $\mathbf{2 5}$ & 63.9 & 49.2 & 38.9 & 69.2 & 35.7 \\
\hline $\begin{array}{c}\text { Uhrar } \\
\text { Loop }\end{array}$ & 40 & 32 & $\mathbf{5 8 . 3}$ & 38.9 & 67.8 & 36.1 & 34.7 & $\mathbf{5 9 . 7}$ & 29.2 & 61.1 \\
\hline $\begin{array}{c}\text { Radial } \\
\text { Loop }\end{array}$ & 0 & $\mathbf{5 . 2}$ & 0 & 0 & 0 & 0 & 5.6 & 0 & 0 & 0 \\
\hline Arches & $\mathbf{2 . 5}$ & $\mathbf{5 . 7}$ & 10.1 & 0 & 7.2 & 0 & 10.5 & 1.4 & 1.6 & 3.2 \\
\hline Total & $100 \%$ & $100 \%$ & $100 \%$ & $100 \%$ & $100 \%$ & $100 \%$ & $100 \%$ & $100 \%$ & $100 \%$ & $100 \%$ \\
\hline
\end{tabular}

Ulnar loop pattern on left hand was found most prevalent in both groups, slightly prevalent in medical students.

Table.1 Percentage of fingerprint types in Medical Students.

LT- Left Thumb

LIF- Left Index Finger

LMF- Left Middle Finger

LRF- Left Ring Finger

LLF- Left Little Finger
RT - Right Thumb

RIF- Right Index Finger

RMF- Right Middle Finger

RRF- Right Ring Finger

RLF -Right Little Finger 


\begin{tabular}{|c|c|c|c|c|c|c|c|c|c|c|}
\hline & LT & LIF & LMF & LRF & LLF & RT & RIF & RMF & RRF & RLF \\
\hline Pattern & L1 & L2 & L3 & L4 & L5 & R1 & R2 & R3 & R4 & R5 \\
\hline Whorls & $\mathbf{5 7 . 5}$ & $\mathbf{5 7 . 1}$ & $\mathbf{5 1}$ & 69.8 & $\mathbf{5 7 . 3}$ & 64.8 & $\mathbf{5 6 . 9}$ & $\mathbf{5 6 . 3}$ & 61.2 & 61.1 \\
\hline $\begin{array}{c}\text { Ulnax } \\
\text { Loop }\end{array}$ & 40.0 & 32 & 42.4 & 21.9 & 42.2 & $\mathbf{2 5}$ & 38.4 & 43.7 & 33.2 & 31.9 \\
\hline $\begin{array}{c}\text { Radial } \\
\text { Loop }\end{array}$ & 0 & $\mathbf{5 . 2}$ & 0 & 1.8 & 0 & 0 & 0 & 0 & 0 & 0 \\
\hline $\begin{array}{c}\text { Arches } \\
\text { Total }\end{array}$ & $\mathbf{2 . 5}$ & $\mathbf{5 . 7}$ & 6.6 & 6.5 & 0.5 & 10.2 & 4.7 & 0 & $\mathbf{5 . 6}$ & 7.0 \\
\hline
\end{tabular}

$\overline{\text { Table.2 Percentage of fingerprint types in Medical lab technician students. }}$

LT- Left Thumb

LIF- Left Index Finger

LMF- Left Middle Finger

LRF- Left Ring Finger

LLF- Left Little Finger
RT - Right Thumb

RIF- Right Index Finger

RMF- Right Middle Finger

RRF- Right Ring Finger

RLF -Right Little Finger

More number of whorls are seen in both hands in most of the students pursuing Medical lab technician course in the same Medical college. Arch pattern was found in $2^{\text {nd }}$ and $3^{\text {rd }}$ digits of left hand in $10 \%$ of medical students. Radial loop pattern is seen on Index finger of both hands in few medical students and $2^{\text {nd }}, 4^{\text {th }}$ digits of left hands of medical lab technician students.

Diversity of types finger print pattern of ten fingers was found mostly in two types i.e whorls and Ulnar loops.

\section{Conclusion}

174 young male and female students from a Medical College were selected from different courses. Their finger prints were obtained by ink printing method. By analyzing finger prints whorl pattern is the commonest pattern in both groups. Ulnar loops are prevalent in left hand fingers. We found no major difference between two groups. Further studies of appropriate sample size need to be undertaken to develop this research. Point of special consideration is both are cognitive learners. Medical students are more affective learners than Medical lab technician students.

\section{Acknowledgement}

The Authors would like to thank all those students who participated in this study. The Authors also would like to thank Dr.S.V.Kumar, Principal, and Andhra Medical College for according the permission.

\section{References}

[1]. Penrose L.S (1969). Effects of additive genes at many loci compared with those of a set of alleles at one locus in parent-children and sib correlation. Annals of human genetics.33: 15-21

[2]. Penrose L.S and Ohara P.T (1973). The development of the epidermal ridges .Journal of Medical Genetics 10: 201-208

[3]. Nora J.J and Fraser F.C (1989). Medical genetics: Principles and Practice. $3^{\text {rd }}$ edition. Philadelphia : Lea Febiger

[4]. Cannon T.D (1997).The nature and mechanism of obstetric influence in schizophrenia: A review and synthesis of epidemiologic studies

[5]. Schaumann, B.A and Alter, M (1976). Dermatoglyphics in medical disorders. New York: NY Springer-Verlag.

[6]. Rajangam, S, Thomas L.M and Janakiram S.(1995). Dermatoglyphics in Down's syndrome. Journal of Indian Medical Association 93: 10-30.

[7]. Babler W.J (1991). Embryonic development of epidermal ridges and their configurations. Birth Defects Original Article Series. 27:95-112.

[8]. Brown A.S, Schaefer C.A, Wyatt R.J, Goetz R.B, Gorman J.M. and Susser E.S(2000). Maternal exposure to respiratory infections and adult schizophrenia spectrum disorder: A prospective birth cohort study. Schizophrenia Bulletin. 26: 287-295.

[9]. Rossa A, Gutierrez B, Arias B and Fananas L. (2001) Dermatoglyphics and abnormal palmar flexion creases as markers af early prenatal stress in children with idiopathic intellectual disability. Journal of Intellectual Disability Research. 45: 416-423.

[10]. Cummins H, and Midlo C. (1943). Finger prints, palms and soles. New York:Blakinson.

[11]. Gardner H. (1999). Intelligence Reframes: Multiple intelligences for the $21^{\text {st }}$ century. New York: Basic Books.

[12]. Armstrong T. (1994). Multiple intelligence in the class room. Virginir: ASCD.

[13]. Okajima M. (1975). Development of dermal ridge in the fetus. Journal of Medical genetics. 12: 243-250.

[14]. Mostaf Najafi, MD.(2009)Association between finger patterns of Digit II and intelligence quotient level in adolescents. Iran J Pediatr sep 2009; vol 19 (No 3).277-284.

[15]. Reed T, Young RS. Genetic analysis of multivariate fingertip dermatoglyphic factors and comparison with corresponding individual variables. Ann Hum Biol. 1979 Hul-Aug;6(4):357-362. 